\title{
The Improvement of Mini Tuber Production of Granola Potato Cultivar in Aeroponics System
}

\author{
Sugiyono $^{1 *}$, Lucky Prayoga ${ }^{1}$, Elly Proklamasiningsih ${ }^{1}$, Khavid Faozi ${ }^{2}$, Rendie Prasetyo ${ }^{1}$ \\ ${ }^{1}$ Faculty of Biology, Universitas Jenderal Soedirman, Indonesia \\ ${ }^{2}$ Faculty of Agriculture, Universitas Jenderal Soedirman, Indonesia. \\ *Corresponding Author: gieks_sugiyono@ hotmail.com
}

Submitted: 2020-12-30. Revised: 2021-02-11. Accepted: 2021-03-07

\begin{abstract}
Potato is an important food crop in both developed and developing countries and it is the fourth most important food crop after wheat, maize, and rice. Potato production in Indonesia has decreased in recent years, mainly due to the use of low quality tuber seed. The objective of this research was to determine the effect of plant materials, types of nutrient and planting densities on mini tuber formation, as well as to determine the best aeroponics conditions for mini tuber production of Granola cultivar of potato. This research has been carried out experimentally using a Split-split Plot Design. The main plot was planting materials which consisted of plantlet and knol. The subplot was the type of nutrition media which consisted of Farran nutrition, Otazu nutrition, and AB-commercial mix. The sub-sub-plot was planting density which consisted of 50, 75, and 100 plants $/ \mathrm{m}^{2}$. The research results showed that knol planted in aeroponics system on AB-commercial mix at a planting density of 75 plants $/ \mathrm{m}^{2}$ resulted in the best mini-tuber production. In this study, for the first time three important factors for potato mini-tuber production have thoroughly been investigated in Indonesia. This finding will be used by Kledung Horticultural Seed Garden, Temanggung, for mass production of high-quality mini-tuber seed, which in turn will provide sufficient tuber seed for the farmer in its surrounding areas. By increasing the production of high-quality tuber seed, it is expected that it will contribute to the improvement of potato productivity and increase Indonesian potato production.
\end{abstract}

Key words: granola; aeroponic; nutrient; mini tuber

How to Cite: Sugiyono, Prayoga, L., Proklamasiningsih, E., Faozi, K., \& Prasetyo, R. (2021). The Improvement of Mini Tuber Production of Granola Potato Cultivar in Aeroponics System. Biosaintifika: Journal of Biology \& Biology Education, 13(1), 77-83.

DOI: http://dx.doi.org/10.15294/biosaintifika.v13i1.27714

\section{INTRODUCTION}

Potato is one of the most important staple food in many parts of the world and an integral part of the world's food supply (Alva et al., 2011; Devaux et al., 2014). In recent years, the demand for potato in Indonesia has increased, but its production has not been able to meet the increase in market demand. Potato production in Indonesia has increased from $1,219,270$ tonnes (2015) to $1,284,780$ tonnes (in 2018), but this production was lower than that of in 2014, which was $1,347,815$ tonnes (Statistics Indonesia, 2018). Indonesian potato production is hindered by the difficulty in providing high-quality seeds in the right quantity and cultivar (Waluyo \& Karyadi, 2013), unfavorable climates, and problems caused by pests and diseases (Agustina et al., 2019; Fahim et al., 2013; Samiyarsih et al., 2018). Granola is one of the yellow potato cultivars which is widely cultivated in Indonesia. This superior cultivar has an average harvest time of 90 days, with productivity reaching 30-40 tons per hectare, and more resistant to diseases.

In vitro propagation method is one of the most suitable alternative methods for producing micro tuber seed because large numbers of clones can be produced in a short time at a lower cost (Badoni \&
Chauhan, 2010), can be produced all year around, easy to be stored and transported (Nistor et al., 2010), as well as improved quality of seed tubers (Donnelly et al., 2003). In addition to micro tuber, shoots and plantlets can also be produced via in vitro propagation techniques. These shoots, plantlets, or micro tubers can be used as planting materials for mini tubers production in aeroponics system.

The use of aeroponic techniques for mini tubers production offers several advantages compared to other methods because this technique can optimize the aeration of the roots, is independent of the season, yields more tuber seed, is more effective, does not lose fertility, and is easy to harvest. The aeroponics success of potatoes is influenced by several factors, including cultivar, water, plant material, aeroponic systems, media, and aeroponic spacing/planting density (Chiipanthenga et al., 2012; Faramarzi et al., 2012; Farran \& Mingo-Castel, 2006; Khodadadi et al., 2011; Mbiyu et al., 2012; Otazu, 2010; Tsoka, O., 2012). Optimation of tuber seed production is widely possible due to the fact that: 1) different cultivars may need different nutrient formulation or concentration; 2) planting materials play a very important role in tuber formation; 3) Each cultivar needs different planting space or density; and 4) the importance of plant growth regulators on potato mini 
tuber formation (Chiipanthenga et al., 2012; Mbiyu et al., 2012; Otazu, 2010; Tsoka, O., 2012).

The objective of this research was to determine the effect of plant materials, types of nutrient, and planting densities on mini-tuber formation, as well as to determine the best aeroponics conditions for minituber formation of Granola cultivar of potato. It is expected that the best aeroponics conditions will be found and in turn can be applied by Kledung Horticultural Seed Garden Temanggung, one of the most important potato tuber seed producers in Central Java, to produce high-quality tuber seed in the form of mini-tuber. It is also expected this technology will increase tuber seed production to provide sufficient tuber seed for the farmer in its surrounding areas. In the longer term, it is expected that it will contribute to the improvement of potato productivity and increase Indonesian potato production to meet the everincreasing demand for potatoes.

\section{METHODS}

This research was conducted in Kledung Horticultural Seed Garden, Temanggung, Central Java Province, Indonesia. This research was carried out experimentally using a Split-split Plot Design. The main plot consisted of in vitro-derived plantlets (and hereafter is called plantlet) and certified-G1tuber-seed-derived plantlets (and hereafter called $k n o l)$. The subplot was the type of nutrition media which consisted of Farran nutrition, Otazu nutrition, and AB-commercial mix. The sub-sub-plot was planting density which consisted of 50,75, and 100 plants $/ \mathrm{m}^{2}$. Each treatment combination was repeated 3 times which resulted in 54 experimental units.

\section{Aeroponics system}

The aeroponics system was set in the greenhouse. Three cubicles (sized $300 \times 60 \times 50 \mathrm{~cm}$ ) were used and represented three nutrients used. The media sprinklers were set at $30 \mathrm{~cm}$ below plant holders. Media was pumped, sprinkled, and circulated back to the media container using a water pump, one pump for each nutrient used. The plant holders were made of styrofoam covered with black plastic mulch. Holes were made using $2-\mathrm{cm}$ cork borer and set according to the planting density applied.

Media were prepared and the $\mathrm{pH}$ was adjusted according to manuals as published in Farran \& Mingo-Castel (2006), Otazu (2010), and AB-Mix manufacturer respectively. Each medium was placed in a 100-liter container located below the aeroponic cubicles. The media was replaced every week. The media containers were closed and protected from direct sunlight to avoid both unwanted contamination and chemical changes.

Both types of plantlets were acclimatized on a compost-cocopeat media in the greenhouse for four weeks. Well-acclimatized and grown plants with similar vigor were used in this study. The plants were cut just above the root and dipped in fungicide solution for at least 15 minutes. The plants were cut with similar diameter $(5 \mathrm{~mm})$ and length $(10 \mathrm{~cm})$ and planted on the planting holders supported with a plastic sponge. At least $5 \mathrm{~cm}$ of the stem should penetrate below the planting holders to facilitate contact with the media. Media were then pumped and sprinkled for 15 minutes toward the basal of the stem cutting at 45 minutes intervals. A regular check was carried out to make sure that the media was sprinkled both nicely and evenly, as well as preventing accidental blocking of the nozzle. Plant maintenance was also performed to make sure no pest and disease interfere plant's growth. Plants were grown for 12 weeks.

\section{Data collection and statistical analysis}

The variable observed was the production of minitubers, with parameters measured including total number, total weight, average weight, and average diameter of the mini-tuber. Data were collected at the end of the research period. An analysis of variance (ANOVA), followed by an Honestly Significant Difference (HSD) test at $95 \%$ level of confidence were used to analyse the data obtained from this study.

\section{RESULTS AND DISCUSSION}

The research results showed that mini tuber formation of Granola cultivar of potato on the aeroponics system was controlled by the planting material, nutrition medium, and the planting density applied. The results showed that the growth of Granola cultivar potato in this aeroponic system was quite good (Figure 1) and produced 2-21 mini tubers/plant, with an average of 5 tubers/plant (300 tubers $/ \mathrm{m}^{2}$ ). Bag et al. (2015) reported that the number of mini tubers produced reached 38.12 micro tubers/plant on the Kufri Himalini cultivar potato. Meanwhile, Rykaczewska (2016) reported that the average micro tuber production of Ametyst and Typhoon cultivars was 32.5 and 36.0 micro tubers/plant, respectively. 


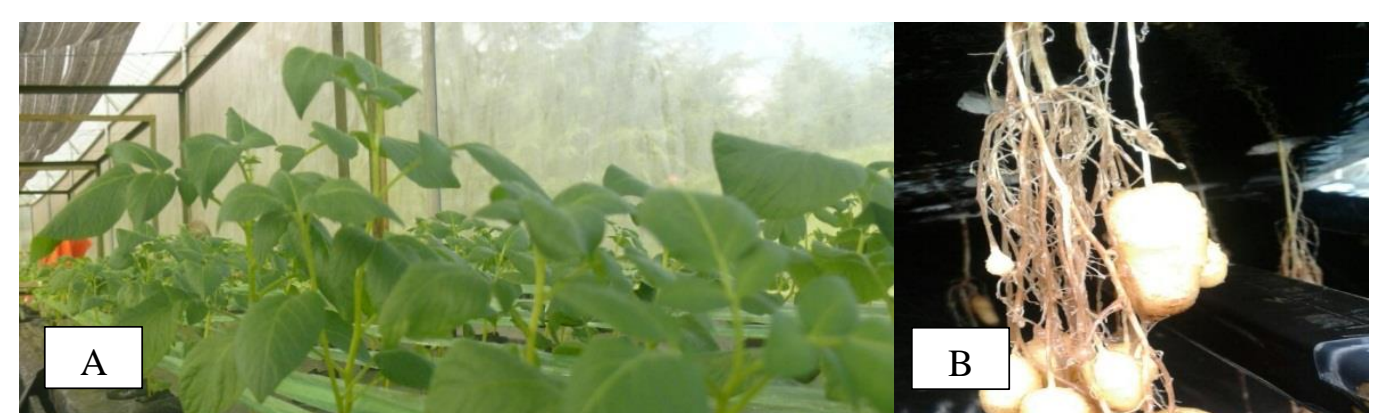

Figure 1. The appearance of Granola potato cultivar in an aeroponics system: A) Plant performance at 4 weeks after planting, B) Mini tubers formed at 8 weeks after planting.

Morphological growth of the tuber consists of two steps, i.e., the development of stolons and the production of tubers on stolon tip. The cells within the pit and cortex expand and continue to differentiate longitudinally, resulting in swelling of the stolon. The longitudinal cell division ends until the tuber reaches $0.8 \mathrm{~cm}$ in diameter (Bradshaw \& Bonierbale, 2010; Gao et al., 2014)

The total number of mini tubers, total mini tuber weight, average mini tuber weight, and average mini tuber diameter were controlled by either planting materials, nutrients, planting density, interactions between factors, or interactions among factors tested. HSD test results on the influence of planting materials on all parameters measured (Table 1) showed that knol produced a significantly better total number of mini tubers, total mini tuber weight, and average mini tuber weight than those of plantlet. No significant difference was found on the average mini tuber diameter produced, although knol still produced a larger mini-tuber diameter.

The growth and mini tuber production of Granola cultivar of potato originated from tuber seed $(\mathrm{knol})$ under the aeroponic system were better than that of plantlets. It is suggested that the plantlet produced from tuber seed have better morphological and anatomical structures as well as physically stronger than that of in vitro derived-plantlet. The morphological dan anatomical structures of in vitro- derived plantlets usually have not fully developed which resulted in both plant vulnerability and slower growth especially in the early stage of plant development during or just after acclimatization. A good acclimatization process is therefore needed (Otazu, 2010). This finding was contradictory with that of reported by Otazú (2010) and Jelodutar \& Hassanpanah (2012), who found that in vitro-derived plantlets produced the best mini-tuber formation.

The results of HSD test on the effect of nutrient formulation on mini tuber formation (Table 2) showed that $\mathrm{AB}$-mix media resulted in a significantly better total number of mini tubers, total mini tuber weight, average mini tuber weight, and average mini tuber diameter than those of Farran and Otazu nutrient formulations. This result indicated that Farran dan Otazu nutrients have not been able to stimulate better mini tubers formation as reported by Farran \& Mingo-Castel (2006) and Otazu (2010). However, these results were consistent with previous experiment reported by Sugiyono et al. (2015) and Prayoga et al. (2015), that Farran and Otazu media formulations showed no difference with modified Hoagland and Grow More in producing mini tubers in the aeroponics system. Sugiyono et al. (2015) and Prayoga et al. (2015) suggested that Grow Moremodified medium could substitute Farran and Otazu media.

Table 1. The effect of different planting materials on mini tuber formation of Granola cultivar of potato in aeroponics system

\begin{tabular}{ccccc}
\hline Type of planting material & Total mini tuber number & $\begin{array}{c}\text { Total mini tuber } \\
\text { weight }\end{array}$ & $\begin{array}{c}\text { Average mini } \\
\text { tuber weight }\end{array}$ & $\begin{array}{c}\text { Average mini } \\
\text { tuber diameter }\end{array}$ \\
\hline Planlet & $1.87 \mathrm{~b}$ & $0.79 \mathrm{~b}$ & $0.44 \mathrm{~b}$ & 0.96 \\
Knol & $2.13 \mathrm{a}$ & $1.73 \mathrm{a}$ & $0.76 \mathrm{a}$ & 1.06 \\
\hline
\end{tabular}

Note: Numbers followed by different letters show a significant difference in HSD $(\leq 0.05)$ 
Table 2. The effect of nutrient formulations on mini tuber formation of Granola cultivar of potato in aeroponics system

\begin{tabular}{lcccc}
\hline Nutrient & Total mini tuber number & $\begin{array}{c}\text { Total mini tuber } \\
\text { weight }\end{array}$ & $\begin{array}{c}\text { Average mini tuber } \\
\text { weight }\end{array}$ & $\begin{array}{c}\text { Average mini tuber } \\
\text { diameter }\end{array}$ \\
\hline Farran & $2.10^{\mathrm{b}}$ & $1.06^{\mathrm{b}}$ & $0.57^{\mathrm{b}}$ & $1.05^{\mathrm{a}}$ \\
Otazu & $1.33^{\mathrm{c}}$ & $0.60^{\mathrm{c}}$ & $0.47^{\mathrm{b}}$ & $0.88^{\mathrm{b}}$ \\
AB- & $2.57^{\mathrm{a}}$ & $2.12^{\mathrm{a}}$ & $0.76^{\mathrm{a}}$ & $1.10^{\mathrm{a}}$ \\
Mix & & & & \\
\hline
\end{tabular}

Note: Numbers followed by different letters show a significant difference in HSD $(\leq 0.05)$

HSD test result also showed that planting density at 75 plants $/ \mathrm{m}^{2}$ resulted in a significantly higher total number and a total weight of mini tubers than that of 50 plants $/ \mathrm{m}^{2}$ planting density, although in term of the total number of mini tubers formed, it was not significantly different with 100 plants $/ \mathrm{m}^{2}$ planting density (Table 3 ). Despite no significant difference was observed, planting density at $50 \mathrm{plants} / \mathrm{m}^{2}$ tended to produce heavier and bigger mini tubers than those of 75 and 100 plants $/ \mathrm{m}^{2}$ planting densities. With regard to the number of mini tubers, this finding was quite similar to the number of mini-tuber reported by Sugiyono et al. (2015) and Prayoga et al. (2015), who applied 60 plants $/ \mathrm{m}^{2}$ planting density. Those findings also indicated that planting density at $60-100$ plants $/ \mathrm{m}^{2}$ in the aeroponics system resulted in no nutrient competition among Granola cultivar of potato. In other words, at $60-100$ plants $/ \mathrm{m}^{2}$ planting density, nutrient supply was not a limiting factor for plant growth and mini tuber formation of Granola cultivar of potato in aeroponics system. It also strongly indicated that nutrient and growth conditions determine growth and mini tuber formation of Granola cultivar of potato under aeroponics system.

Further analysis results on the effect of interaction between planting materials and nutrients (Table 4) showed that knol planted on AB-mix nutrient produced the highest results, and significantly different with those of other treatment combinations except on the average of mini tuber weight. HSD test results on the effect of the interaction between planting materials and planting densities on mini tuber formation of Granola cultivar of potato (Table 5) showed that $\mathrm{knol}$ planted at $75 \mathrm{plants} / \mathrm{m}^{2}$ resulted in a significantly better total number of mini tubers, total mini tuber weight, average mini tuber weight, and average mini tuber diameter than those of other interaction between planting material and planting density. The largest average tuber diameter was obtained at knol planted at looser spacing i.e., 50 plants $/ \mathrm{m}^{2}$, although it was not significantly different from that of 75 plants $/ \mathrm{m}^{2}$ planting density.

The number and weight of mini tuber as well as the plant height were influenced by the cultivar, planting density, and the interaction between those two factors applied (Faramarzi et al., 2012). Similar results were also reported by Khodadadi et al. (2011) in Savalan cultivar-that the formation of mini tubers was controlled by planting density and cultivars planted.

The HSD test results on the effect of the interaction between nutrients and planting densities (Table 6) also showed that Granola cultivar of potato planted on AB-mix nutrient at a planting density of 75 plants $/ \mathrm{m}^{2}$ also resulted in a significantly higher number and hevier weight of mini tuber than those of other treatment interactions. The largest average mini tuber diameter was obtained from plants cultivated in Farran medium at 50 plants $/ \mathrm{m}^{2}$ planting density, although no significant difference was observed compared to that of produced by plants grown on AB-Mix nutrient at 75 plants $/ \mathrm{m}^{2}$ planting density. HSD test results on the interaction between planting materials and nutrients, nutrients and planting densities, and planting materials and planting densities, strongly indicated that knol grown on $\mathrm{AB}-$ mix nutrient at 75 plants $/ \mathrm{m}^{2}$ planting density could be the best conditions to obtain better mini tuber formation of Granola cultivar of potato in aeroponics system. Results of the HSD test on the effect of the interaction among planting materials, nutrients, and planting densities on mini tuber formation of Granola cultivar of potato in aeroponics system (Table 7) reconfirmed the results of two factors interaction. Results on Table 7 showed that knol grown on ABMix nutrient at 75 plants $/ \mathrm{m}^{2}$ planting density resulted in the highest total number of mini-tubers (4.40 minitubers/plant) and heavier mini-tuber weight $(5,12$ grams/plants). In general, these results were significantly different from those of other treatment interactions. Although the number of mini tubers formed by knol grown on AB-Mix nutrient at 75 plants $/ \mathrm{m}^{2}$ planting density was not significantly different with knol grown on AB-Mix nutrient at 100 plants $/ \mathrm{m}^{2}$ planting density, it produced bigger and heavier mini-tubers. These results also showed that three factors interactions produced much better mini tuber formation compared to individual factor and two-factor interactions. 
Table 3. The effect of planting densities on mini tuber formation of Granola cultivar of potato in aeroponics system

\begin{tabular}{|c|c|c|c|c|}
\hline $\begin{array}{ll}\begin{array}{l}\text { Planting } \\
\left(\text { plants } / \mathrm{m}^{2}\right)\end{array} & \text { density } \\
\end{array}$ & Total mini tuber number & $\begin{array}{l}\text { Total mini tuber } \\
\text { weight }\end{array}$ & $\begin{array}{l}\text { Average mini } \\
\text { tuber weight }\end{array}$ & $\begin{array}{c}\text { Average mini tuber } \\
\text { diameter }\end{array}$ \\
\hline 50 & $1.43^{\mathrm{b}}$ & $0.93^{\mathrm{b}}$ & 0.65 & 1.08 \\
\hline 75 & $2.33^{\mathrm{a}}$ & $1.68^{\mathrm{a}}$ & 0.64 & 1.02 \\
\hline 100 & $2.23^{\mathrm{a}}$ & $1.17^{\mathrm{b}}$ & 0.51 & 0.93 \\
\hline
\end{tabular}

Note: Numbers followed by different letters show a significant difference in $\operatorname{HSD}(\leq 0.05)$

Table 4. The effect of the interaction between planting materials and nutrients on mini tuber formation of Granola cultivar of potato in aeroponics system

\begin{tabular}{lccccc}
\hline $\begin{array}{l}\text { Planting } \\
\text { material }\end{array}$ & Nutrient & Total mini tuber number & $\begin{array}{c}\text { Total mini } \\
\text { tuber weight }\end{array}$ & $\begin{array}{c}\text { Average mini } \\
\text { tuber weight }\end{array}$ & $\begin{array}{c}\text { Average mini tuber } \\
\text { diameter }\end{array}$ \\
\hline \multirow{4}{*}{ Plantet } & Farran & $2.33^{\mathrm{b}}$ & $0.71^{\mathrm{cd}}$ & $0.35^{\mathrm{ns}}$ & $0.98^{\mathrm{bc}}$ \\
& Otazu & $1.33^{\mathrm{c}}$ & $0.47^{\mathrm{d}}$ & $0.37^{\mathrm{ns}}$ & $0.94^{\mathrm{bc}}$ \\
& AB-mix & $1.93^{\mathrm{bc}}$ & $1.17^{\mathrm{bc}}$ & $0.60^{\mathrm{ns}}$ & $0.53^{\mathrm{bc}}$ \\
\hline \multirow{3}{*}{ Knol } & Farran & $1.86^{\mathrm{bc}}$ & $1.39^{\mathrm{b}}$ & $0.79^{\mathrm{ns}}$ & $1.11^{\mathrm{ab}}$ \\
& Otazu & $1.33^{\mathrm{c}}$ & $0.72^{\mathrm{cd}}$ & $0.56^{\mathrm{ns}}$ & $0.82^{\mathrm{c}}$ \\
& AB-mix & $3.20^{\mathrm{a}}$ & $3.05^{\mathrm{a}}$ & $0.91^{\mathrm{ns}}$ & $1.25^{\mathrm{a}}$ \\
\hline
\end{tabular}

Note: Numbers followed by different letters show a significant difference in $\operatorname{HSD}(\leq 0.05)$

Table 5. The effect of the interaction between planting materials and planting densities on mini tuber formation of Granola cultivar of potato in aeroponics system

\begin{tabular}{lccccc}
\hline $\begin{array}{l}\text { Planting } \\
\text { material }\end{array}$ & $\begin{array}{c}\text { Planting density } \\
\left(\text { plants } / \mathrm{m}^{2}\right)\end{array}$ & Total mini tuber number & $\begin{array}{c}\text { Total mini } \\
\text { tuber weight }\end{array}$ & $\begin{array}{c}\text { Average mini } \\
\text { tuber weight }\end{array}$ & $\begin{array}{c}\text { Average mini } \\
\text { tuber diameter }\end{array}$ \\
\hline \multirow{3}{*}{ Planlet } & 50 & $1.33^{\mathrm{c}}$ & $0.60^{\mathrm{b}}$ & $0.49^{\mathrm{c}}$ & $0.98^{\mathrm{ab}}$ \\
& 75 & $2.06^{\mathrm{ab}}$ & $0.75^{\mathrm{b}}$ & $0.37^{\mathrm{c}}$ & $0.91^{\mathrm{ab}}$ \\
& 100 & $2.20^{\mathrm{ab}}$ & $1.00^{\mathrm{b}}$ & $0.46^{\mathrm{c}}$ & $0.98^{\mathrm{ab}}$ \\
\hline \multirow{3}{*}{ Knol } & 50 & $1.53^{\mathrm{bc}}$ & $1.25^{\mathrm{b}}$ & $0.81^{\mathrm{ab}}$ & $1.18^{\mathrm{a}}$ \\
& 75 & $2.60^{\mathrm{a}}$ & $2.60^{\mathrm{a}}$ & $0.90^{\mathrm{a}}$ & $1.13^{\mathrm{ab}}$ \\
& 100 & $2.27^{\mathrm{a}}$ & $1.32^{\mathrm{b}}$ & $0.55^{\mathrm{bc}}$ & $0.87^{\mathrm{b}}$ \\
\hline
\end{tabular}

Note: Numbers followed by different letters show a significant difference in HSD $(\leq 0.05)$

Table 6. The effect of the interaction between nutrients and planting densities on mini tuber formation of Granola cultivar of potato in aeroponics system

\begin{tabular}{lccccc}
\hline Nutrient & $\begin{array}{c}\text { Planting density } \\
\left(\text { plants } / \mathrm{m}^{2}\right)\end{array}$ & Total mini tuber number & $\begin{array}{c}\text { Total mini } \\
\text { tuber weight }\end{array}$ & $\begin{array}{c}\text { Average mini } \\
\text { tuber weight }\end{array}$ & $\begin{array}{c}\text { Average mini } \\
\text { tuber diameter }\end{array}$ \\
\hline \multirow{3}{*}{ Farran } & 50 & $1.40^{\mathrm{cd}}$ & $1.02^{\mathrm{c}}$ & $0.78^{\mathrm{a}}$ & $1.29^{\mathrm{a}}$ \\
& 75 & $2.20^{\mathrm{bc}}$ & $1.21^{\mathrm{bc}}$ & $0.56^{\mathrm{ab}}$ & $1.00^{\mathrm{ab}}$ \\
& 100 & $2.70^{\mathrm{ab}}$ & $0.93^{\mathrm{c}}$ & $0.37^{\mathrm{b}}$ & $0.83^{\mathrm{b}}$ \\
\hline \multirow{3}{*}{ Otazu } & 50 & $1.10^{\mathrm{d}}$ & $0.55^{\mathrm{c}}$ & $0.52^{\mathrm{ab}}$ & $0.90^{\mathrm{b}}$ \\
& 75 & $1.60^{\mathrm{cd}}$ & $0.71^{\mathrm{c}}$ & $0.49^{\mathrm{ab}}$ & $0.90^{\mathrm{b}}$ \\
& 100 & $1.30^{\mathrm{cd}}$ & $0.52^{\mathrm{c}}$ & $0.38^{\mathrm{b}}$ & $0.84^{\mathrm{b}}$ \\
\hline \multirow{3}{*}{ AB-mix } & 50 & $1.80^{\mathrm{bcd}}$ & $1.20^{\mathrm{bc}}$ & $0.64^{\mathrm{ab}}$ & $1.04^{\mathrm{ab}}$ \\
& 75 & $3.20^{\mathrm{a}}$ & $3.09^{\mathrm{a}}$ & $0.85^{\mathrm{a}}$ & $1.16^{\mathrm{ab}}$ \\
& 100 & $2.70^{\mathrm{ab}}$ & $2.04^{\mathrm{b}}$ & $0.76^{\mathrm{a}}$ & $1.10^{\mathrm{ab}}$ \\
\hline
\end{tabular}

Note: Numbers followed by different letters show a significant difference in HSD $(\leq 0.05)$ 
Table 7. The effect of the interaction among planting materials, nutrients, and planting densities on mini tuber formation of Granola cultivar of potato in aeroponics system

\begin{tabular}{|c|c|c|c|c|}
\hline Planting material & Nutrient & Planting density (plants $/ \mathrm{m}^{2}$ ) & Number of tuber per plant & Total weight of tuber \\
\hline \multirow{9}{*}{ Plantlet } & \multirow{3}{*}{ Farran } & 50 & $1.40^{\mathrm{d}}$ & $0.61^{\mathrm{c}}$ \\
\hline & & 75 & $2.40^{\mathrm{bcd}}$ & $0.63^{\mathrm{c}}$ \\
\hline & & 100 & $3.20^{\mathrm{ab}}$ & $0.90^{\mathrm{bc}}$ \\
\hline & \multirow{3}{*}{ Otazu } & 50 & $1.20^{\mathrm{d}}$ & $0.50^{\mathrm{c}}$ \\
\hline & & 75 & $1.80^{\mathrm{bcd}}$ & $0.55^{\mathrm{c}}$ \\
\hline & & 100 & $1.00^{\mathrm{d}}$ & $0.36^{\mathrm{c}}$ \\
\hline & \multirow{3}{*}{$\mathrm{AB}-\operatorname{mix}$} & 50 & $1.40^{\mathrm{d}}$ & $0.69^{\mathrm{c}}$ \\
\hline & & 75 & $2.00^{\mathrm{bcd}}$ & $1.07^{\mathrm{bc}}$ \\
\hline & & 100 & $2.40^{\mathrm{bcd}}$ & $1.75^{\mathrm{bc}}$ \\
\hline \multirow{9}{*}{ Knol } & \multirow{3}{*}{ Farran } & 50 & $1.40^{\mathrm{d}}$ & $1.44^{\mathrm{bc}}$ \\
\hline & & 75 & $2.00^{\mathrm{bcd}}$ & $1.79^{\mathrm{bc}}$ \\
\hline & & 100 & $2.20^{\mathrm{bcd}}$ & $0.95^{\mathrm{bc}}$ \\
\hline & \multirow{3}{*}{ Otazu } & 50 & $1.00^{\mathrm{d}}$ & $0.60^{c}$ \\
\hline & & 75 & $1.40^{\mathrm{d}}$ & $0.88^{\mathrm{bc}}$ \\
\hline & & 100 & $1.60^{\mathrm{cd}}$ & $0.68^{c}$ \\
\hline & \multirow{3}{*}{$\mathrm{AB}-\operatorname{mix}$} & 50 & $2.20^{\text {bcd }}$ & $1.70^{\mathrm{bc}}$ \\
\hline & & 75 & $4.40^{\mathrm{a}}$ & $5.12^{\mathrm{a}}$ \\
\hline & & 100 & $3.00^{\mathrm{abc}}$ & $2.34^{\mathrm{b}}$ \\
\hline
\end{tabular}

Note: Numbers followed by different letters show a significant difference in HSD $(\leq 0.05)$

In this study, for the first time, three important factors for potato mini-tuber production in aeroponics system have been thoroughly investigated in Indonesia. This finding will be used by Kledung Horticultural Seed Garden, Temanggung, for mass production of high quality mini-tuber seed, which in turn will provide sufficient tuber seed for the farmer in its surrounding areas. By increasing the production of high-quality tuber seed, it is expected that it will contribute to the improvement of potato productivity and increase Indonesian potato production.

\section{CONCLUSION}

The formation of Granola cultivar potato tubers in an aeroponic system is influenced by the plant material, nutrition, and planting density used. Knol planted on $\mathrm{AB}$-mix nutrient at a planting density of 75 plants $/ \mathrm{m}^{2}$ resulted in the best mini tuber production of Granola cultivar potato in the aeroponics system.

\section{AKNOWLEDGEMENT}

The authors wish to thank you The Rector of Jenderal Soedirman University and the Ministry of Research, Technology and Higher Education for the funding through National Strategic Research Grant (Grant No. 2046)

\section{REFERENCES}

Agustina, D., Tarwotjo, U., Rahadian, R., \& Article, H. (2019). The Effectiveness of Plastic Mulch for Maintaining the Potato Farmland in Dieng Plateau Using Soil Biological Quality Index. Biosaintifika: Journal of Biology \& Biology Education, 11(1), 125-131.

Alva, A., Fan, M., Qing, C., Rosen, C., \& Ren, H. (2011). Improving nutrient-use efficiency in chinese potato production: Experiences from the United States. Journal of Crop Improvement, 25(1), 46-85.

Badoni, A., \& Chauhan, J. S. (2010). In vitro Sterilization Protocol for Micropropagation of Solanum tuberosum cv . ' Kufri Himalini .' Academia Arena.

Bag, T. K., Srivastava, A. K., Yadav, S. K., Gurjar, M. S., Diengdoh, L. C., Rai, R., \& Singh, S. (2015). Potato (Solanum tuberosum) aeroponics for quality seed production in north eastern Himalayan region of India. Indian Journal of Agricultural Sciences, 85(10), 1360-1364.

Balali, G. R., Hadi, M. R., Yavari, P., Bidram, H., Naderi, A. G., \& Eslami, A. (2008). Effect of pot size, planting date and genotype on minituber production of Marfona potato cultivar. African Journal of Biotechnology, 7(9), 1265-1270.

Bradshaw, J. E., \& Bonierbale, M. (2010). Root and Tuber Crops. In Root and Tuber Crops.

Chiipanthenga, M., Maliro, M., Demo, P., \& Njoloma, J. (2012). Potential of aeroponics system 
in the production of quality potato (Solanum tuberosum 1.) seed in developing countries. African Journal of Biotechnology, 11(17), 39933999.

Devaux, A., Kromann, P., \& Ortiz, O. (2014). Potatoes for Sustainable Global Food Security. Potato Research, 57(3-4), 185-199.

Fahim, M. A., Hassanein, K. M., Abolmaty, S. M., \& Fargalla, F, H. (2013). Challangers to Crop Pests and Livestock Diseases Management in Irrigated African Agroecosystems under Changing Climate. Researcher, 5(12).

Faramarzi, A., Hassanpanah, D., \& Satarzadeh, R. (2012). The Study of Mini-tuber Production Potential of two Micro-tubers Potato Cultivars in Different Planting Beds under Greenhouse Condition. International Journal of Agronomy and Plant Production, 3(11), 501-507.

Farran, I., \& Mingo-Castel, A. M. (2006). Potato minituber production using aeroponics: Effect of plant density and harvesting intervals. American Journal of Potato Research, 83(1), 47-53.

Gao, Y., Jia, L., Hu, B., Alva, A., \& Fan, M. (2014). Potato stolon and tuber growth influenced by nitrogen form. Plant Production Science, 17(2), 138-143.

Jelodutar, Y. J., \& Hassanpanah, D. (2012). Investigation of qualitative characteristics on potato cultivars micro-tubers under hydroponic and conventional cultivation system. International Journal of Agriculture: Research and Review, 2(4), 336-342.

Khodadadi, M., Hassanpanah, D., Pirovatlo, S. P., \& Masoumi, H. (2011). Evaluation of Different Planting Beds Effect on Mini-Tuber Production of Potato Cultivars under Greenhouse Condition. American-Eurasian J. Agric \& Environ. Sci, 11(3), 365-370.

Mbiyu, M. W., Muthoni, J., Kabira, J., Elmar, G., Muchira, C., Pwaipwai, P., Ngaruiya, J., Otieno, S., \& Onditi, J. (2012). Use of aeroponics technique for potato (Solanum tuberosum) minitubers production in Kenya. Journal of Horticulture and Forestry, 4(11), 172-177.

Nistor, A., Campeanu, G., Atanasiu, N., Chiru, N., \& Karácsonyi, D. (2010). Influence of potato genotypes on "in vitro" production of microtubers. Romanian Biotechnological Letters, 15(3), 53175324.

Otazu, V. (2010). Manual on quality seed potato production using aeroponics. In International potato Centre (CIP). Lima, Peru. 44pp.

Prayoga, L., Sugiyono, Rochmatino, Naipospos, N., Suyanto, \& Dwiningsih. (2015). Pertumbuhan dan produksi kentang kultivar Granola dalam sistem aeroponik. Seminar Nasional Pengembangan Sumber Daya Perdesaan Dan Kearifan Lokal Berkelanjutan $V$.

Rykaczewska, K. (2016). The potato minituber production from microtubers in aeroponic culture. Plant, Soil and Environment, 62(5), 210-214.

Samiyarsih, S., Juwarno, J., \& Muljowati, J. S. (2018). The Structural Resistance's Anatomy of Sweet Potato Leaves to Fungal Pathogen Sphaceloma batatas. Biosaintifika: Journal of Biology \& Biology Education, 10(1), 131-137.

Statistics Indonesia. (2020). Statistika Tanaman Sayuran dan Buah-buahan Semusim Indonesia 2018. Badan Pusat Statistik.

Sugiyono, Faozi, K., Prayoga, L., Proklamasiningsih, E., Suyanto, \& Dwiningsih. (2015). Produksi Umbi Bibit Kentang Kultivar Granola dengan Teknik Aeroponik. Seminar Nasional Pengembangan Sumber Daya Perdesaan Dan Kearifan Lokal Berkelanjutan $V$.

Tsoka, O. (2012). Potato seed tuber production from in vitro and apical stem cutting under aeroponic system. African Journal of Biotechnology, 11(63), 12612-12618.

Waluyo, N., \& Karyadi, A. K. (2013). Produksi Benih Umbi Mini (G0)Kentang (Solanum tuberosum L.) Varietas Granola L. Dan Atlantik M. Nurmalita. 1249-1253. 